\title{
ANALISIS KESULITAN BELAJAR MAHASISWA PADA MATA KULIAH ALJABAR LINEAR (STUDI KASUS PADA MAHASISWA MANAJEMEN INFORMATIKA AKADEMI MANAJEMEN BELITUNG)
}

\author{
Djunaedi Djafar, Eka Indah Wahyuni, Leni Reziyustikha \\ Akademi Manajemen Belitung \\ Email: lenirezi@gmail.com
}

\begin{abstract}
The purpose of this study is to determine the difficulties of students in linear algebra subject. The subject of linear algebra is one of the compulsory subjects in the Informatics Management Study Program. From the last 3 years, in linear algebra subject, students who get below average scores are always there. Difficulties in linear algebra subject need to be analyzed so that it can be known the cause of the difficulties. The study was conducted on informatics management students in 2019/2020. From this study, the causes of difficulties in algebra are 1) the lack of skilled students in integer operations, 2) students didn't thorough, 3) student logic ability is still lacking to do Elementary Row Operations, 4) students doubt in solving problems.
\end{abstract}

Keywords : Learning difficulties, Linear algebra, Matrices

\section{PENDAHULUAN}

Kurikulum Akademi Manajemen Belitung (AMB) pada Program Studi Manajemen Informatika (Prodi MI) memiliki beberapa matakuliah wajib yang harus di ambil mahasiswa. Beberapa diantaranya adalah Mata Kuliah Keilmuan dan Keterampilan (MKK) yang berkaitan dengan matematika yaitu Aljabar Linear, Kalkulus, Matematika Diskrit dan Statistika. Matakuliah tersebut diwajibkan bagi mahasiswa, dengan harapan mahasiswa mempunyai pemikiran yang logis sistematis dan kritis setelah mengikuti matakuliah ini.

Dari beberapa matakuliah wajib pada kurikulum Prodi MI, aljabar linear merupakan salah satu matakuliah yang harus diambil pada semester awal perkuliahan. Berdasarkan observasi dilapangan, hasil pembelajaran aljabar linear berdasarkan tiga tahun terakhir ditunjukkan pada tabel berikut.

Tabel 1. Hasil Belajar Aljabar Linear dalam Tiga Tahun Terakhir pada Prodi Manajemen Informatika

\begin{tabular}{|c|c|c|c|c|}
\hline \multicolumn{2}{|c|}{ Tahun Akademik } & $\begin{array}{l}2015 / \\
2016 \\
\end{array}$ & $\begin{array}{l}2016 / \\
2017 \\
\end{array}$ & $\begin{array}{l}2017 / \\
2018 \\
\end{array}$ \\
\hline \multicolumn{2}{|c|}{ Nilai Terbesar } & 98,8 & 100 & 93,3 \\
\hline \multicolumn{2}{|c|}{ Nilai Terkecil } & 38,0 & 40,6 & 31,4 \\
\hline \multicolumn{2}{|c|}{ Rata-rata } & 65,5 & 73,7 & 66,5 \\
\hline \multicolumn{2}{|c|}{ Standar Deviasi } & 16,4 & 16,2 & 20 \\
\hline \multirow{2}{*}{$\begin{array}{c}\text { Banyak } \\
\text { Mahasiswa }\end{array}$} & $\begin{array}{c}\text { Di Bawah } \\
\text { Rata-rata }\end{array}$ & 9 & 9 & 15 \\
\hline & $\begin{array}{c}\text { Di Atas } \\
\text { Rata-rata }\end{array}$ & 17 & 14 & 15 \\
\hline
\end{tabular}

Berdasarkan tabel di atas, dari tahun ke tahun pada mata kuliah aljabar linear, sebanyak $50 \%$ mahasiswa mendapat nilai dibawah nilai rata-rata. Kemudian dilihat dari penyebaran data, pada tahun terakhir terjadi kenaikan standar deviasi yang berarti bahwa semakin lebar variasi datanya semakin besar rentang nilai yang diperoleh.

Pencapaian nilai yang baik dapat didukung dengan adanya pembelajaran yang efektif, pelaksanaannya mengacu pada rencana pembelajaran, dan didukung oleh suasana dan penggunaan metode yang tepat. Soewandi (2005) mengatakan bahwa efektivitas pembelajaran lebih ditekankan kepada hasil belajar yang dapat dicapai, jangka waktu pencapaiananya, dan jangka waktu bertahannya sesuatu.

Ada beberapa faktor yang menyebabkan suatu pembelajaran menjadi efektif. Menurut Uno dan Muhammad (2013), faktor faktor yang mempengaruhi efektivitas dalam pembelajaran ditinjau dari faktor internal siswa dan pendekaran belajar. Faktor yang dimaksud meliputi aspek fisiologis yang merupakan kondisi siswa yang dapat mempengaruhi semangat dan konsentrasi dalam belajar, serta aspek psikologis yang meliputi intelegensi siswa, siskap siswa dan bakat siswa.

Peneliti merancang suatu analisis kesulitan belajar mahasiswa pada matakuliah aljabar linear. Kesulitan belajar menurut 
Rumini dkk dalam Irham dan Wiyani (2013) yaitu suatu kondisi saat siswa mengalami hambatan-hambatan tertentu untuk mengikuti proses dan mencapai hasil belajar secara optimal. Pengertian lain tentang kesulitan belajar menurut Djamarah dalam Lestari (2015) yaitu suatu kondisi dimana mahasiswa tidak dapat belajar secara wajar disebabkan adanya ancaman, hambatan, maupun gangguan dalam belajar. Kesulitan belajar adalah kondisi dimana siswa/mahasiswa menghalami hambatan dalam mencapai hasil belajar.

\section{METODE}

Penelitian ini mengenai studi kasus tentang kesulitan belajar pada mata kuliah Aljabar Linear pada materi matriks. Subjek pada penelitian ini berjumlah 15 orang mahasiswa Program Studi Manajemen Informatika di Akademi Manajemen Belitung semester ganjil tahun ajaran 2019/2020.

Metode yang digunakan adalah pendekatan penelitian kualitatif dengan metode deskriptif yaitu dengan mendekripsikan gejala peristiwa atau kejadian yang timbul dalam penelitan. Data diperoleh dari data tes dengan melihat hasil jawaban mahasiswa dengan indikator kesulitan mahasiswa yang akan diteliti. sedangkan data non tes di ambil dari data angket yang disebar kepada mahasiswa yang berisi pertanyaan mengenai kesulitan yang terjadi ketika belajar pada mata kuliah aljabar linear.

\section{HASIL DAN PEMBAHASAN}

Dari 4 soal yang diberikan kepada mahasiswa, jawaban mahasiswa dikelompokkan menjadi 6 bagian yaitu 1) kesalahan membaca soal, 2) kesalahan konsep, 3) kesalahan keterampilan aljabar, 4) kesalahan dalam pemecahan masalah, 5) tidak menjawab soal dan 6) tidak menemui kesulitan. Penjabaran dalam pengelompokan kesalahan tersebut yaitu sebagai berikut. Kesalahan membaca soal yang dimaksud adalah kesalahan mahasiswa dalam membaca soal dan memindahkan kedalam lembar jawaban. Kesalahan konsep adalah kondisi dimana siswa kurang memahami konsep yang ada pada materi. Kesalahan keterampilan aljabar adalah kondisi dimana terjadi kekeliruan pada operasi aljabar termasuk kesalahan penulisan dalam matematika. Kesalahan dalam pemecahan masalah adalah kondisi mahasiswa tidak menyelesaikan soal sampai selesai. Tidak menjawab soal yaitu mahasiswa tidak mengisi jawaban sama sekali. Tidak menemui kesulitan artinya siswa menjawab soal tersebut dengan benar.

Tabel 2. Jenis Kesalahan Menjawab Soal

\begin{tabular}{ccccc}
\hline No Absen & \multicolumn{4}{c}{ Jenis Kesalahan (No Soal) } \\
\cline { 2 - 5 } Mahasiswa & $\mathbf{1}$ & $\mathbf{2}$ & $\mathbf{3}$ & $\mathbf{4}$ \\
\hline 1 & $\mathrm{~B}$ & $\mathrm{C}$ & $\mathrm{B}, \mathrm{C}, \mathrm{D}$ & $\mathrm{D}$ \\
2 & $\mathrm{~A}$ & $\mathrm{C}$ & $\mathrm{C}, \mathrm{D}$ & $\mathrm{E}$ \\
3 & $\mathrm{~F}$ & $\mathrm{~F}$ & $\mathrm{E}$ & $\mathrm{E}$ \\
4 & $\mathrm{~F}$ & $\mathrm{~F}$ & $\mathrm{~F}$ & $\mathrm{D}$ \\
5 & $\mathrm{~A}, \mathrm{C}$ & $\mathrm{C}$ & $\mathrm{B}$ & $\mathrm{D}$ \\
6 & $\mathrm{~A}$ & $\mathrm{C}$ & $\mathrm{C}$ & $\mathrm{E}$ \\
7 & $\mathrm{C}$ & $\mathrm{F}$ & $\mathrm{E}$ & $\mathrm{E}$ \\
8 & $\mathrm{C}$ & $\mathrm{F}$ & $\mathrm{E}$ & $\mathrm{E}$ \\
9 & $\mathrm{C}$ & $\mathrm{F}$ & $\mathrm{F}$ & $\mathrm{E}$ \\
10 & $\mathrm{~A}$ & $\mathrm{C}$ & $\mathrm{F}$ & $\mathrm{E}$ \\
11 & $\mathrm{~A}$ & $\mathrm{~F}$ & $\mathrm{C}$ & $\mathrm{E}$ \\
12 & $\mathrm{~A}$ & $\mathrm{~F}$ & $\mathrm{~B}$ & $\mathrm{D}$ \\
13 & $\mathrm{~A}$ & $\mathrm{~F}$ & $\mathrm{C}$ & $\mathrm{E}$ \\
14 & $\mathrm{~F}$ & $\mathrm{~A}, \mathrm{C}$ & $\mathrm{F}$ & $\mathrm{F}$ \\
15 & $\mathrm{C}, \mathrm{B}$ & $\mathrm{F}$ & $\mathrm{C}, \mathrm{D}$ & $\mathrm{E}$ \\
\hline
\end{tabular}

Keterangan :
A. Kesalahan Membaca Soal
D. Pemecahan
B. Kesalahan Masalah
E. Tidak Di Isi
Konsep
C. Keterampilan
Aljabar
F. Tidak
Menemui
Kesulitan

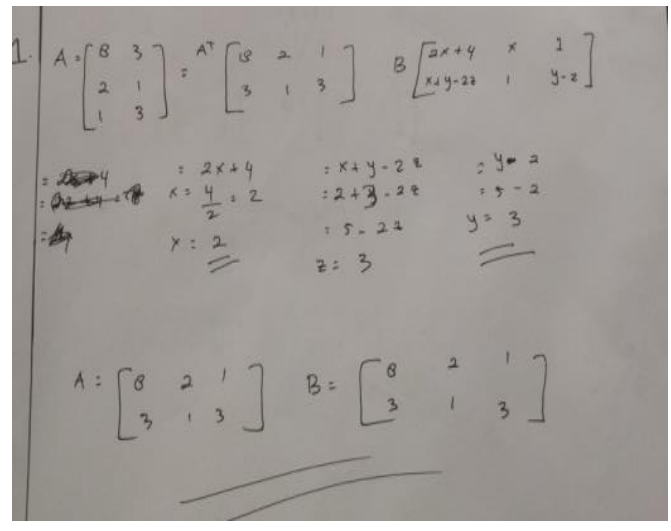

Gambar 1. Contoh Jawaban Mahasiswa 1 pada Soal Nomor 1 


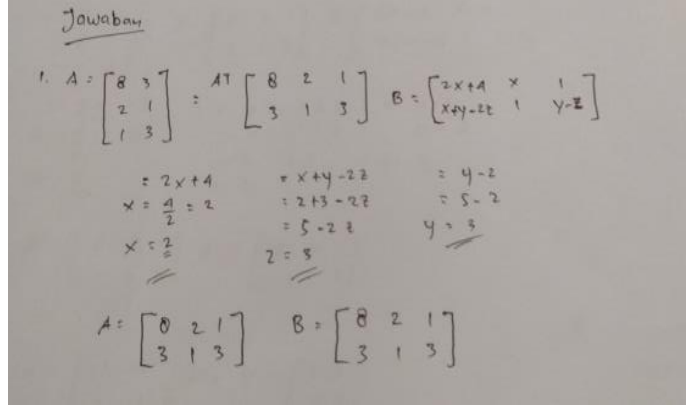

Gambar 2. Contoh Jawaban Mahasiswa 2 pada Soal Nomor 1

Pada soal no 1 terdapat 6 mahasiswa yang salah membaca soal, 2 orang yang salah konsep, dan 5 orang salah dalam keterampilan aljabar. Berdasarkan pengelompokan tersebut, pada kesalahan membaca soal, mahasiswa keliru dalam memahami pertanyaan pada soal yang diberikan. Pertanyaan pada soal adalah menentukan kesamaan matriks tetapi mahasiswa tidak membaca soal dengan benar, sehingga mereka menyelesaikan soal tanpa membuat kesamaan. Selanjutnya, setelah diperiksa, kekeliruan juga terjadi pada operasi perkalian dan pembagian.Kesalahan lain yang terjadi adalah kesalahan konsep dalam menentukan suatu kesamaan matriks.

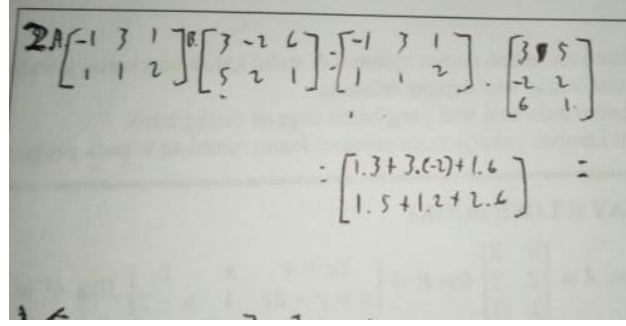

Gambar 3. Contoh Jawaban Mahasiswa 3 pada Soal Nomor 2

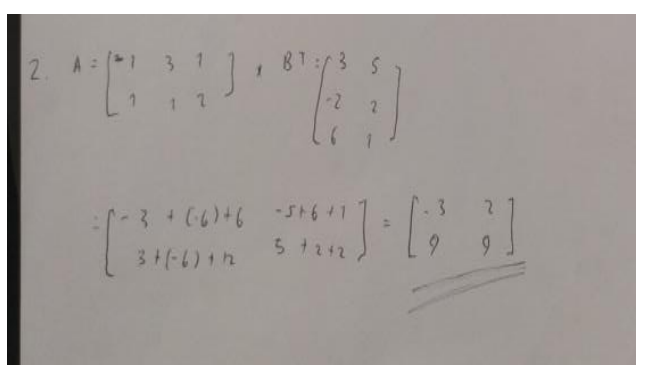

Gambar 4. Contoh Jawaban Mahasiswa 4 pada Soal Nomor 2
Berdasarkan jawaban mahasiswa pada soal nomor 2 terdapat mahasiswa yang melakukan kesalahan dalam membaca soal danketerampilan aljabar. Kesalahan membaca soal terjadi ketika mahasiswa salah memindahkan soal ke lembar jawaban. Kemudian dari hasil analisis jawaban, terdapat mahasiswa yang mengetahui proses penyelesaian, akan tetapi terjadi kekeliruan dalam menuliskan jawaban. misalkan proses perkalian operasi matrik seharusnya adalah (1) di kali dengan 3 , tetapi mahasiswa tersebut menuliskan (1) dikali dengan 3.

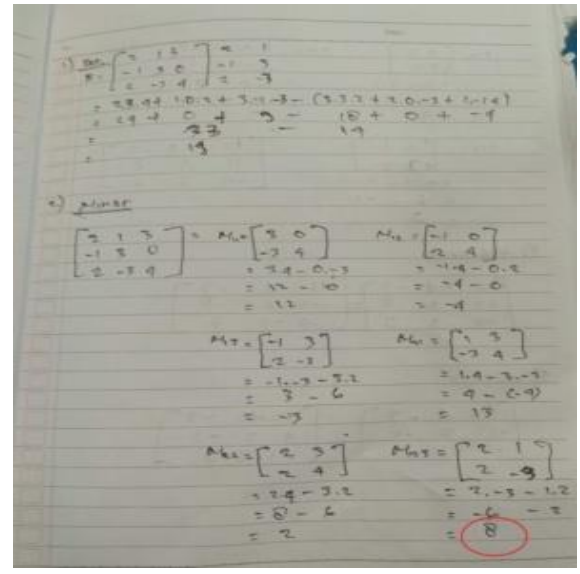

Gambar 5. Contoh Jawaban Mahasiswa 5 pada Soal Nomor 3

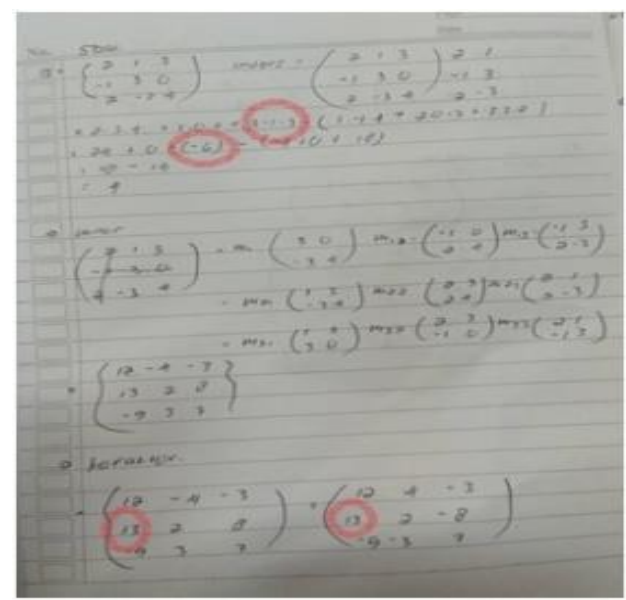

Gambar 6. Contoh Jawaban Mahasiswa 6 pada Soal Nomor 3

Pada soal nomor 3 terdapat tiga mahasiswa yang salah dalam pemahaman konsep, tiga orang tidak menyelesaikan jawaban yang sudah diisi, enam orang 
melakukan kesalahan pada keterampilan aljabar dan tiga orang tidak mengisi jawaban. Jika dilihat dari proses pengerjaan, mahasiswa memahami proses pengerjaannya, akan tetapi terdapat kekeliruan dalam proses penjumlahan dan pengurangan. Mahasiswa kurang teliti dalam proses aljabar. Contoh kekeliruan, mahasiswa menulis jawaban $(3) \times(-1) \times$ (3) $=(-6)$. Terdapat juga mahasiswa membuat kekeliruan dalam menjumlah hasil minor. Hal ini berpengaruh pada hasil determinan yang diperoleh. Selain itu juga terjadi kekeliruan pada kofaktor. Selain itu, terdapat mahasiswa yang tidak menyelesaikan jawabannya. Ketika ditanya mereka menjawab karena ragu dengan hasil yang mereka peroleh. mereka juga mengatakan bahwa lupa dengan rumus yang diberikan, sehingga mereka memutuskan untuk tidak melanjutkan menyelesaikan jawaban.

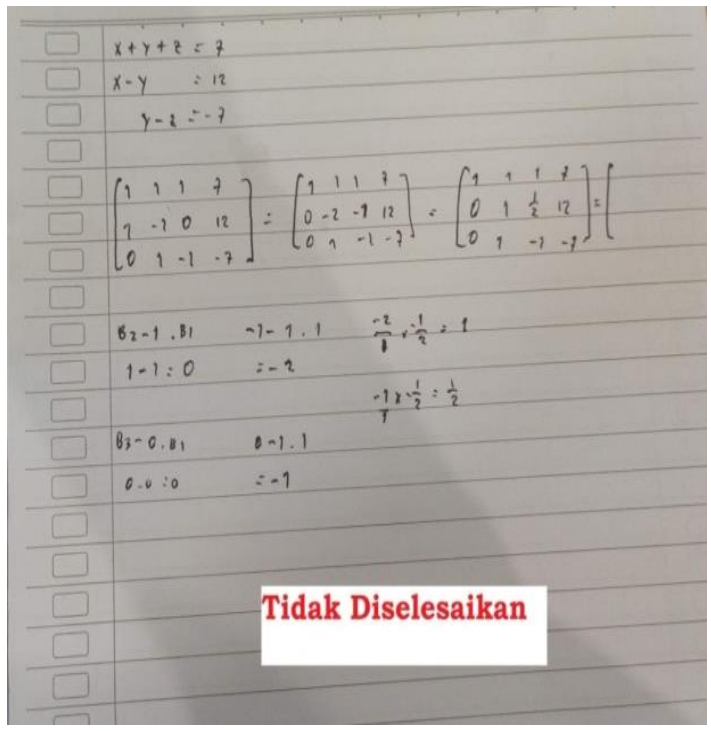

Gambar 7. Contoh Jawaban Mahasiswa 7 pada Soal Nomor 4

Analisis jawaban mahasiswa untuk soal nomor 4, terdapat empat mahasiswa yang tidak menyelesaikan jawaban, dan 10 orang tidak mengisi jawaban. Mahasiswa tidak menyelesaikan jawaban yang diberikan dikarenakan kehabisan waktu untuk menjawab. Ini dikarenakan mereka kurang cepat dalam menghitung. Terdapat juga mahasiswa yang hanya menuliskan model matematika dari soal tanpa menyelesaikannya. Ketika diwawancara mengenai alasannya, mahasiswa menajawab belum bisa dalam menggunakan OBE. Selain itu, ada pula mahasiswa yang tidak menyelesaikan jawabandikarenakan lupa cara menyelesaikan soal. Mahasiswa juga bingung bagaimana cara memperoleh rumus OBE agar nilai matrisk kolom 1 menjadi 1,0,0.

Berdasarkan soal yang diberikan kepada mahasiswa dan dari hasil wawancara kepada mahasiswa mengenai kesulitan apa yang dialami ketika belajar mata kuliah aljabar matriks, beberapa menjawab kesulitan dalam membuat rumus-rumus untuk menentukan OBE. Dalam penentuan rumus ini perlu suatu logika, sehingga didapat rumus yang tepat untuk menyelesaikan OBE. Kemudian beberapa mahasiswa merasa kesulitan ketika soal yang diberikan berbeda dengan yang ada di contoh soal. Mereka kebingungan menentukan langkah selanjutnya. Sebagian mahasiswa lain sudah mengerti mengenai hal tersebut dan mengerjakannya dengan tepat. Tapi ada mahasiswa yang kurang teliti. Mereka mengerjakan dengan tahapan-tahapan yang sesuai dengan OBE akan tetapi kurang teliti pada perkalian atau pengurangan, sehingga menyebabkan hasil akhir menjadi kurang tepat. Ketidaktelitian terjadi dalam proses penjumlahan, perngurangan, perkalian.

\section{SIMPULAN}

Hasil penelitian yang didapat yaitu mahasiswa mengalami kesulitan dalam menyelesaikan soal materi matriks yangkebanyakan disebabkan karena mahasiswa kurang teliti dalam menyelesaikan soal. Penyebab dari kesulitan ini diantaranya sebagai berikut.

1) Kurang terampilnya mahasiswa dalam melakukan operasi pada bilangan bulat.

2) Tinggiya tingkat ketidaktelitian pada mahasiswa

3) Kemampuan logika mahasisswa yang masih kurang, terlihat dari beberapa mahasiswa yang tidak mengisi jawaban karena kurang paham mengenai cara melakukan OBE

4) Ragu-ragu dalam menyelesaikan masalah. Hal ini juga menyebabkan mereka memilih untuk tidak menyelesaikan jawaban.

Jika dilihat dari jawaban mahasiswa, kesalahan yang dilakukan mahasiswa dibagi menjadi kesalahan membaca soal, kesalahan konsep, keterampilan aljabar dan pemecahan 
PRINSIP Pendidikan Matematika

Volume 2, Nomor 1, November2019

masalah. Kesulitan mahasiswa dalam belajar aljabar linear dikarenakan keterampilan aljabar yang masih rendah. Hal ini dilihat dari hampir seluruh penyebab dari kesalahan mahasiswa adalah ketidaktelitian dalam menjawab akibat kesalahan operasi hitung.

\section{REKOMENDASI}

Peneliti merekomendasikan untuk melakukan penelitian pada sampel yang lebih besar. Selain itu, analisis kesulitan mahasiswa dapat dilakukan pada mata kuliah dan materi yang lainnya.

\section{DAFTAR PUSTAKA}

Irham, M. dan Wiyani, N.A. (2013). Psikologi Pendidikan Teori dan Aplikasi dalam Proses Pembelajaran. Jogjakarta: ArRuzz Media
Lestari, A.S.B. (2015). Analisis Kesulitan Belajar Mahasiswa Program Studi Pendidikan Matematika STKIP PGRI Pasuruan Pada Pokok Bahasan teknik Pengintegralan, Jurnal Psikologi, 3(1), 20-27

Uno, H.B. dan Muhammad, N.(2012).Belajar dengan Pendekatan PAILKEM. Jakarta: PT Bumi Aksara

Soewandi dkk. (2005). Perspektif Pembelajaran di Berbagai Bidang Studi. Yogyakarta: Sanata Dharma University Press. 